Archaeological Journal

\title{
Opening Address to the Historical Section at the Derby Meeting
}

\section{the Very Reverend}

To cite this article: the Very Reverend (1885) Opening Address to the Historical Section at the Derby Meeting, Archaeological Journal, 42:1, 389-397, DOI: 10.1080/00665983.1885.10852181

To link to this article: http://dx.doi.org/10.1080/00665983.1885.10852181

曲 Published online: 15 Jul 2014.

Submit your article to this journal $๘$

Q View related articles $\sqsubset$ 


\title{
The Archaenlagical $\mathfrak{j}$ ourmal.
}

\author{
DECEMBER, 1885.
}

\section{OPENING ADDRESS TO THE HISTORICAL SECTION AT THE DERBY MEETING. ${ }^{1}$}

By the Very Reverend the DEAN OF LICHFIEID.

I feel much honoured in being called upon to preside over the Historical Section of the Royal Archæological Institute on this occasion; and I must ask you to listen with indulgence to one, who, although he has always felt an interest in pursuits of this kind, has been chiefly occupied, during a busy life, with studies more immediately connected with his sacred calling.

Archæology, if I rightly understand the term, comprises the pursuit of every thing which tends to illustrate history, or to increase our knowledge of the lives and habits of our forefathers. All those relics, which time or disaster have spared to us, come within the province of history, and even words and names and proverbs and popular traditions are of the number of those things with which it is conversant. We all know how much light has been thrown upon the history of our country by an intimate and critical acquaintance with its composite language; and hence I feel sure of your sympathy when I say that we are not at all obliged to the advocates of a system of what is called "phonetic spelling," which would sweep away many an interesting and instructive historical land mark.

The history of our country is really enshrined in its language. We find stereotyped in our words of daily use the intimations of the past fortunes of our land ; and we can trace out in those words the history of our connection

1 Read at Derby, July 28th, 1885.

VOL. XLII. (No. 168). 
with other nations, and the relations which we have held to them; and we can thus measure the amount of influence which successive invasions have exercised upon us. And thus too do the patient researches of the archrologist in another direction reveal to us those material fragments and remnants which have come to us "tanquam tabulæ ex naufragio" ; and by means of which we can construct the proofs and furnish the illustrations of successive foreign occupations of our island. But I need hardly remind this audience that there are portions of our history still remaining in much obscurity. Something has been done in recent times by the skill and patient research of men like Professor Rhys, Prebendary Scarth, Mr. Elton and others, to lift the cloud of obscurity which rests upon our most ancient traditions. I call them ancient, although I do not forget the dictum of Bacon, "Antiquitas sæculi, juventus mundi." "Those times," he says, "are the ancient times, when the world is ancient, and not those which we account ancient, ' ordine retrogrado,' by a computation backward from ourselves." Then again, anything which tends to illustrate the period between the Roman and the Saxon dominations, is of peculiar value, as exhibiting the influence exerted upon our forefathers by the Roman occupation of our island. That influence I apprehend to have been far greater both in its political and religious aspect than is commonly supposed. Let me add further that we are living in an age in which these relics are rapidly disappearing. The disturbances of the soil, caused by the general enclosure and cultivation of waste lands, and by the formation of railways and other extensive works (to say nothing of the density of our population) have a direct tendency to displace, if not to sweep away, what remains to us of the materialism of antiquity. Now this Institute has been and will, I doubt not, continue to be of eminent service in rescuing some of these memorials, in receiving and imparting light respecting them, and in treasuring up facts, which will help to enrich the pages of some future historian of our country.

I will venture to remind you of some of the more interesting of the discoveries by which in recent times light has been shed upon our history. 
I would first mention the aids which have been afforded to us by coins and medals. It was Addison, I think, who said that "medals give a very great light to history, in confirming such passages as are true in old authors, in determining such as are told after different manners: and in recording such as have been omitted. In this case a cabinet of medals is a body of history'."

The history of Britain in the interval between the invasions of Julius and Claudius Cresar, namely from 54 B.C. to 43 A.D. is chiefly to be learnt from the coins. The coinage of Britain was modelled after that of Gaul, which in its turn can be traced to the Greeks of Masilia or Marseilles, through whom the Gauls became acquainted with the gold stater of Philip II. of Macedon, about 350 B.c. This coin had on one side the head of Apollo, wreathed with laurel, and on the other a charioteer driving a pair of horses; underneath the chariot is the name of Pliilip. This beautiful Greek coin was fairly imitated by the Gauls at first; but by degrees the figures degenerated into grotesque and fantastic forms. Mr. Joln Evans, the greatest living authority on this subject, is of opinion that the inhabitants of the south and south-east of Britain must have begun to coin gold pieces of this kind from 200 to 150 B.c. There is one portion of this island whose history is curiously illustrated by the peculiarity of its coinage, namely, the country of the Iceni or Eceni, embracing that part of the island now known, speaking roughly, as Norfolk and Suffolk. These Iceni were a brave and hardy race. They made an alliance with the Romans about 43 B.c. Some of their coins are remarkable as shewing the name of the people to whom the coin belonged, in the abbreviated form of Ecen., from which it has been conjectured ingeniously by the Professor of Celtic at Oxford, that these Eceni may have had a revolution which put an end to the kingly power. At all events the Professor gives it as his opinion that they were never conquered by Cymbeline.

The Celts, with whom our.ideas of the earliest inhabitants of this country are most identified, are a branch of

\footnotetext{
I In connection with this I may refer to an interesting work entitled, "Merlallic lllustrations of the History of Great Britain and Ireland to the death of
}

George II," compiled by the late Fdwird Hawkins, F.L.S. and Herbert A. Grueber; recently printed by order of the T'rustees of the British Museum. 
the great family of nations called Aryan. Those who appear most frequently in history are the race called Gothic, the name indicating that they were warriors. No one knows when they first settled in Britain. There appear to have been two invasions of the Celtic races properly so called. To the one race belong the ancestors of the people who speak Gaelic in Ireland, in the Isle of Man, and in the Highlands; the other group is represented in point of speech by the Welsh people and the Britons. The Welsh form of this word is Brython. The ancient Gauls must be classed with them; for the Brythons must be regarded as Gauls who came over to settle in Britain.

The Brythons appear to have invaded England later than the Gaelic, or Goidelic people, and to have driven them westwards. And here I may observe in passing; that the great movements of the earth's population have for the most part been from east to west. But the Goidels when they arrived in this island did not find it without inhabitants. They had previously driven another race westward. Thus there are indications of three different races, two Celtic and one pre-Celtic, the pre-Celtic being a people whose remains belong to an age called the "later Stone age." It is probably to this remote period that such vast megalithic structures as those of Avebury and Stonehenge are to be referred; and also the earthworks, or fortified camps remaining in elevated positions; the most elaborate and most strongly fortified being generally regarded as the most ancient. Then there are also the barrows to be seen in Wiltshire, and in this your county of Derby. These barrows appear upon examination to have been the sepulchres of a rude and primitive people. And it is singular and interesting that interments of Romans have sometimes been found in mounds outside these barrows, evidently of later work.

What then is the earliest historical information that we possess of our island? There were two ways by which it might be approached from the east, through the Mediterranean. One would be throngh the Straits of Gibraltar (the pillars of Hercules, as they were called); the other by land through Gaul, and so across the narrow channel which separates it from England. Now it appears that about 350 B.C. an expedition was fitted out by some 
merchants of Marseilles, to ascertain whether a trade in tin might not be opened out with advantage in certain unknown regions lying north.west of Spain. It was known in these early times that there was a trade in tin carried on in the west of this island; and that it was purchased from the natives by merchants, who came for it from Gaul to the eastern shores of Britain. Now amongst those who formed the expedition to which I have just referred, was an eminent astronomer named. Pytheas, a native of Marseilles. His works unfortunately have perished; but fragments of his diary have been preserved in ancient authors. He sailed through the pillars of Hercules, and round the coast of Spain and Brittany, and thence to Kent, and other parts of the shores of Britain. He went northwards at least as far as Shetland; but he paid more attention to Britain than to any other country. Curiously enough, however, he does not appear to have visited the tin district at the south-west corner of the island; nor does he give a hint to shew that there was any communication between those districts and the continent. That intercourse was probably confined to the south-east of the island, where the channel, the "silver streak" as it has been called, is narrowest. It is possible that commercial reasons may have restrained him from saying anything about the trade in tin then existing between Cornwall, the ancient Damnonia, and Gaul. But he gives some interesting facts with reference to the inhabitants of Britain at that time. They were so far civilized as to have become agriculturists; at all events the south-east corner of England was at that time a rich corn-producing district. These early tillers of the soil had large barns in which the corn was thrashed out; for the climate of this island was very much the same 2000 years ago that it is now ; and the British farmer can trace his ancestry to at least the third century before Christ.

Another eminent Greek, named Posidonius, a contemporary and friend of Cicero, visited Britain about 80 B.C., and extended his travels to the extreme south-west corner of the island, the furthest extremity of Cornwall, which he named Belesius, where tin was found. He describes the people, and their methods of working tin. He says that 
their dwellings were mean, made for the most part of reeds and wood; and that their harvest consisted in cutting off the ears of corn, and storing them in pits underground. Thus the necessities of the climate compelled the inhabitants at that remote period to have recourse to a system of ensilage, not very different from that which is coming into use in this generation for storing food for animals.

We cannot learn much from ancient authors as to the religion of our forefathers. It is probable that Druidism had found its home in Britain amongst the pre-Celtic inhabitants before the two Celtic invasions. But we may reasonably infer that so far as they were Celts they brought with them into this island the religion of the Gauls and other Aryan nations. The gods whom they worshipped would be, roughly speaking, those of Rome, such as Jove and Minerva, Apollo and Mars, and especially Mercury. It must not however be forgotten that during the time of the Roman occupation, which lasted more than three centuries and a half, Christianity made considerable progress amongst the Celts. It appears in all probability to have planted itself in this island in the time of Claudius; nor is there any reason to doubt the truth of the tradition that the apostle St. Paul actually visited this island in the interval between his first and second imprisonments at Rome. This interval comprised some eight years. We know that he contemplated a journey into Spain; and if we combine with the words of St. Clement, his contemporary, who says that he came to "the extreme limit of the west," those of Tertullian A.D. 208 "the places of the Britons, inaccessible to the Romans, are subdued to Christ," we can hardly doubt that the Church in this island was planted by apostolic hands. The Latin language also became prevalent during that period. It was the official language of the province, and the ordinary means of communication over the south and south eastern portions of the island. York, Lincoln, Colchester, and London were the strongholds of the Roman dominion; and the municipal institutions of Rome had to a great extent established themselves in Britain. But the prevailing spirit of the country was military, rather than civil, a spirit which was no doubt fostered by its insular position, and its liability 
to invasion from barbarians on all sides. And it is recorded by Bæda (li. c. xii) that when the Romans were about to leave the island, they helped the inhabitants to build a strong stone wall from sea to sea in a straight line connecting the fortified towns which had been built, not far from the walls of Severus, to protect them from the Picts and the Scots. They also built a series of towers at regular intervals on the south eastern shore, within sight of the sea, which were designed to assist the inhabitants in their defence of the country. Nor need I remind you that the Romans have also left their mark on this island in the roads the remains of which still exist, and whose names indicate their origin; as the "Watling Street," so called from Vitellianus, who is supposed to have directed it, and whose name was corrupted by the Britons into "Guatelin"; the "Ickneild Way" from the Iceni or Eceni, in whose country it began; and the "Ermin Street" from the German "Irmunsul" meaning "Mercury," the favourite God of the Gauls.

We have been accustomed to regard Brittany in France, as having derived its name from the Bretons, when they were driven from England by the Saxons; a tradition which has been perpetuated by Milton when he speaks of "British and Armoric Knights" as the customary retinue of king Arthur (Paradise Lost, Book I. 579). But recent ethnological investigations, for which we are indebted to the Oxford Celtic Professor; have I think thrown a new light on this matter. The Professor is of opinion that the question turns very much upon the source from whence the word Britain is derived. $\mathrm{He}$ thinks that this word, together with the Welsh Brydan, or Prydan, must be traced back to the Latin, which was commonly written Britannia. The inhabitants of this island were known to the Romans as Britanni. Now it is probable that it was from the Greeks of Marseilles that the Romans first heard of these islands; and it is equally probable that the Greeks heard the word from the natives of the south-west part of the island, who brought their tin in market. When however the Romans came to Britain, they found that the name which the Brythens gave themselves in the south-east of the island was not Britanni, but Brittones (singular Britto), which among the Welsh becomes 
Brythen. Now the root of this word has to do with cloth or clothing; and thus the Professor makes out Brythen to mean a "clothed people," as distinguished from a people wearing little or no clothing. Who then, he asks, could this people be? Not the Celts, either of the first or of the second invasion; because the art of making clothes seems to have been known to the earliest of those who ever landed here. He concludes, therefore, that the unclothed race, with whom the Brythens favourably contrasted themselves, must have been some of the aboriginal tribes whose country they invaded on the continent; especially as there are reasons for believing that they called themselves Brythens, before they invaded England. In fact, remnants of this people are supposed to shew traces of their existence in Gaul in historic times. Pliny speaks of continental Britanni, who lived on the borders of the Rhine; and it is believed that most, if not all the regiments termed Brittones in the Roman army in Britain were natives of Gaul. At all events the old tradition that Brittany was colonized by fugitive Brythens from this country is of doubtful authority.

But I must not detain you longer. Allow me to remind you in conclusion that it is the province of Archieology to assist in moulding the mind of successive ages. Tpon the archæologist lies the grave responsibility of helping to transmit that which is truth to posterity, with as little admixture of error as human infirmity will admit. We should learn wisdom therefore by the faults as well as by the merits of our prerlecessors, and endeavour to hand on the history of the past, checked by what the present has revealed, and chastened by the genius and scholarship of our age.

But surely this is not the only end, or the ultimate scope of our aims. "The greatest error," says Bacon, "is the mistaking or misplacing of the last or furthest end of knowledge. For men have entered into a desire of learning and knowledge, sometimes upon a natural curiosity or inquisitive appetite,-sometimes to entertain their minds with variety and delight,-sometimes for ornament and reputation; and sometimes to enable them to victory of wit, and contradiction : and most times for lucre and profession; and seldom sincerely to give a true 
account of their gift of reason to the benefit and use of men; as if there were sought in knowledge a couch whereon to rest a searching and restless spirit; or a terrace for a wandering and variable mind to walk up and down with a fair prospect; or a tower of state for a proud mind to raise itself upon; or a fort or commanding ground for strife and contention; or a shop for profit or sale; and not a rich storehouse for the glory of the Creator, and the relief of man's estate." And if this is true of all knowledge, how true is it of those pursuits in which we are engaged. It is surely an object of laudable ambition to strive to gather up such facts as may aid us in constructing a more exact and copious history of the past. But it would be an unprofitable result indeed, if our spirits were to slumber in the midst of the materialism of our work, and we were to accustom ourselves to examine a coin, or to trace the etymology of a word, or to endeavour to reconcile conflicting statements, without drawing for ourselves the moral lessons which these studies suggest. Even the rusted ring of the Roman knight may tell us of the end of human ambition; for the earth which has kept his ring: could not keep him ; and the little hoarded treasure, it may be of the 12th century, which the ploughshare of the 19 th century has turned up, may speak to us of some unprospered act of covetousness or theft. The pursuits of archæology are indeed full of moral and spiritual lessons. Happy are those students who, while adding to the stock of general knowledge, are thereby bracing and elevating themselves. 